\title{
CLIMATE CHANGE: IMPLICATIONS FOR ENGINEERING GEOLOGY PRACTICE
}

\author{
J NATHANAIL $^{1} \&$ V BANKS ${ }^{2}$ \\ ${ }^{1}$ Land Quality Management, Nottingham, UK \\ ${ }^{2}$ British Geological Survey, Keyworth, Nottingham, UK
}

\begin{abstract}
The key questions addressed in this paper are: What is climate change? What are the impacts on engineering geology practice? Can engineering geologists contribute to mitigation of climate change? What research areas are engineering geologists involved with? Where should the focus for future research be? Following an overview of the papers presented for the Legacy of the Past and Future Climate Change Session of the $10^{\text {th }}$ Congress of the International Association for Engineering Geology and the Environment, this paper reviews the sources of information and current models of climate change. An overview of some of the potential impacts of climate change on engineering geology practice follows. Attention has been given to areas of active research, the potential impacts on the more routine work of the engineering geologist and on the way in which the engineering geologist can contribute to climate change mitigation and adaptation. It is concluded that current planning guidance addresses climate change more fully than current engineering practice and it is considered that there are considerable research areas open to engineering geologists with regard to potential impacts of climate change. More specifically, it has been noted that current engineering practice draws heavily on empirical approaches to design and it is suggested that this approach should be reviewed in the context of climate change. Attention is given to a number of mitigating measures, such as: ground source heat pumps, carbon sequestration, the "reduce, reuse and recycle" approach to achieving sustainability and sustainable urban drainage systems (SUDS).
\end{abstract}

Key words: Climate change, engineering geology, mitigation.

\section{INTRODUCTION}

A review of the papers presented to the Legacy of the past and future climate change Session of the $10^{\text {th }}$ Congress of the International Association for Engineering Geology and the Environment (IAEG) suggests that, currently, engineering geology is focused on the monitoring of, and design of mitigating measures against, impacts of eighteenth and nineteenth century industrialisation (Genske \& Ruff [2009], Hall et al. [2009], Hatheway \& Doyle [2009], Yu et al. [2009] and Sayre \& Bulbulkaya [2009]) and mineral exploitation (Brooks et al. [2009], Culshaw et al. [2009], Clarke et al. [2009], Devleeschouwer [2009], Devleeschouwer et al. [2009], Donnelly et al. [2009], Ferreira et al. [2009], Gorog \& Torok [2009], Heitfield et al. [2009], Konstantopoulou \& Hayiou [2009], Maximovich [2009], Sherman \& Partington [2009] and West \& Cho [2009]). Few papers directly dealt with current climate change research, exceptions being: Dixon et al. (2009), Glendinning et al. (2009) and Rees et al. (2009). Other relevant publications include: Fookes \& Lee (2007) and British Geological Survey (2007).

It might be argued that investigation of the impacts of industrialization dates back to 1966 and the Aberfan disaster. Thus, it took at least a century for the effects of industrialization to form an integral part of environmental and engineering research. This time-scale is not available for monitoring, modelling and militating against the effects of climate change (Barton [2009] and Meehl et al. [2000]). Furthermore, the effects of climate change are not directly comparable with those of industrialization. Although past climate change gives an indication of the potential consequences of climate change, for example rates and potential magnitude of sealevel rise (Kim \& Yang [2009]), it is difficult to constrain the geological evidence (for example, Forster et al. [2009]). One of the key legacies of research associated with post-industrialization has been the development of increasingly sophisticated monitoring techniques; for example, the radar interferometry techniques described by Birch \& Warren (2009) and Culshaw et al. (2009). These technologies are considered an invaluable feedback for current and future research in all areas of engineering geology, including those related to climate change.

Two of the papers reported on continuing research into the effects of climate change (Dixon et al. [2009], Glendinning et al. [2009]). The keynote address outlined aspects of modelling that are being undertaken in the context of effects of climate change (Rees et al. [2009]). Barton (2009), reviewed the predictions for climate change with reference to the IPPC Third Assessment report. Given the urgency that results from the rate of climate change (Barton [2009], Meehl et al. [2000], IPCC [2007a]) the authors were of the opinion that a review 
of what climate change will mean for practicing engineering geologists would be a beneficial contribution to the Congress Proceedings. Since the Congress, the issue of climate change has become much more widely recognised, as highlighted in the recently published United Nations Environment Programme report (UNEP [2007]).

Griffiths \& Culshaw (2004) identified that one way to ensure the future development of engineering geology, as an independent subject in the UK, would be to ensure the continuance of a thriving research culture. This paper suggested that the components of engineering geology identified by Waltham (2002) form a good basis upon which to subdivide engineering geology in the context of identifying potential research areas. These categories also form a convenient structure within which to consider potential impacts of climate change on engineering geology practice. The components identified were:

- Ground materials and structures

- Regional characteristics

- $\quad$ Surface processes and materials

- Ground investigations

- Material properties

- Difficult ground conditions

To this the authors of this paper have added:

- the role of engineering geology in climate change mitigation, adaptation and polity development;

- contaminant transport processes (following the suggestion of Griffiths \& Culshaw (2004, p. 4)) "if 'environmental geology' is to be correctly regarded as a part of engineering geology”,the underpinning requirement for sustainability demands increased cross-cutting collaboration.

\section{CLIMATE CHANGE}

Evidence for climate change comes from a variety of disciplines. Broadly, it is driven by an increased energy input to the global system. Energy inputs include, firstly, heat trapping as a consequence of increases in carbon dioxide resulting in lower reflection of solar energy; secondly, ozone layer depletion allows more incoming solar energy radiation; and thirdly, increased solar energy radiation as a consequence of reductions in particle haze (Barton, in press; IPCC, 2007a). Changes to these factors are described in terms of radiative forcing (IPCC 2007a), a numerical descriptor of the impacts on global warming (positive values) and cooling (negative values). The rate of increase in radiative forcing during the industrial period is much greater than any increase in over 10 000 years (IPCC 2007a). The radiative forcing due to carbon dioxide, alone, increased by 20\% between 1995 and 2005. The radiative forcing from increased concentrations of carbon dioxide, methane and nitrous oxide together over the industrial period is $+2.30 \mathrm{~W} \mathrm{~m}^{-2}$ (IPCC 2007a). Other factors that affect radiative forcing, include land cover, which affects surface albedo and ozone concentrations in the stratosphere and troposphere. Aerosols in the atmosphere have a cooling effect: a direct radiative forcing of $-0.5 \mathrm{~W} \mathrm{~m}^{-2}$ and an indirect forcing (cloud albedo) of $-0.7 \mathrm{~W} \mathrm{~m}^{-2}$. The key driver is the concentration of atmospheric carbon dioxide and other atmospheric gases.

Atmospheric gas concentrations have been directly measured since about the 1960s. Geochemical evidence of gas concentration is also gained by measuring gas concentrations in ice cores.. IPCC (2007a) reported that the concentration of carbon dixoide, methane and nitrous oxide (greenhouse gases) have all increased since the commencement of the Industrial Revolution in Britain (Table 1). Despite increased consciousness of the need for sustainability, the rate of increase in concentration of carbon dioxide has actually been greater in the past 10 years (1995-2005 average: 1.9 ppm per year) than that since continuous direct atmospheric measurements started (1960-2005 average: 1.4 ppm per year) (IPCC 2007a). In contrast to carbon dioxide, the rate of growth in methane concentrations has reduced in the past approximately 15 years (IPCC 2007a). Table 1 shows the likely causes of increase of these gases as reported by IPCC (2007a).

Table 1. Increases in greenhouse gas concentrations and major sources

\begin{tabular}{|l|l|l|l|l|}
\hline Gas & $\begin{array}{l}\text { Pre-Industrial } \\
\text { concentration }\end{array}$ & $\begin{array}{l}\mathbf{2 0 0 5} \\
\text { concentration }\end{array}$ & Percentage increase & Major sources \\
\hline $\begin{array}{l}\text { Carbon } \\
\text { dioxide }\end{array}$ & $280 \mathrm{ppm}$ & $379 \mathrm{ppm}^{3}$ & $35 \%$ & $\begin{array}{l}\text { Fossil fuel } \\
\text { Land use change }\end{array}$ \\
\hline Methane & $715 \mathrm{ppb}$ & $1774 \mathrm{ppb}$ & $148 \%$ & $\begin{array}{l}\text { Fossil fuel } \\
\text { Agriculture } \\
\text { Relative contribution from various }\end{array}$ \\
\hline
\end{tabular}




\begin{tabular}{|l|l|l|l|l|}
\hline & & & & sources not well defined \\
\hline $\begin{array}{l}\text { Nitrous } \\
\text { oxide }\end{array}$ & $270 \mathrm{ppb}$ & $319 \mathrm{ppb}$ & $18 \%$ & Agriculture \\
\hline
\end{tabular}

Geologists have shown that changes in greenhouse gas concentration are not solely due to anthropogenic effects.. Griffiths \& Pedley (1995) suggested that gas bubbles trapped within Arctic, Antarctic and Greenland ice-cores document a significant increase in atmospheric carbon dioxide levels between the last glacial maximum, when concentrations were in the order of 180-200 ppmv, and the late Holocene, when concentrations were in the order of 270ppmv. Forster et al. (2009) referred to the major climate changes associated with the glacial period. Fookes \& Lee (2007) reviewed some natural causes of climate change in the past, including variations in the earth's orbit, ocean currents, and volcanic eruptions.

\section{SOURCES FOR CLIMATE CHANGE SCENARIO FORECASTS}

To predict the effect of climate change on matters relevant to engineering geology, it is necessary to understand the potential impacts of climate change. Information on predicted climate change scenarios can be found in Table 2, some of which were listed by Hulme \& Turnpenny (2004). Of these, UKCIP has a useful web site that presents a summary of both baseline climate datasets and future climate scenario datasets. Carbon dioxide determinations measured at the Mauna Loa station, Hawaii, USA (Bacastow et al. 1985) provide another useful dataset (the longest continuous record of carbon dioxide concentrations in the world) and are representative of global carbon dioxide trends, showing an increase from $315.83 \mathrm{ppm}$ in 1959 to $362.57 \mathrm{ppm}$ in 1996 . Climate change scenarios and the secondary impacts such as increased flooding or decreased river flow vary for different part of the world. IPCC (2007b) summarised typical impacts for each continent including what might happen to ecosystems, economies and health etc.. Table 3 is largely derived from IPCC (2007b) and lists the anticipated changes to climate and some secondary impacts of potential relevance to engineering geology.

Table 2. Organisations providing information on predicted climate change scenarios.

\begin{tabular}{|c|c|c|}
\hline Name of organisation & Website & Notes \\
\hline $\begin{array}{lll}\text { Intergovernmental } & \text { Panel } & \text { on } \\
\text { Climate Change }^{1} & & \\
\end{array}$ & www.ipcc.ch & Established in 1988 \\
\hline $\begin{array}{l}\text { Environmental Change Institute } \\
\text { Oxford University }{ }^{1} \text {, }\end{array}$ & www.eci.ox.ac.uk & Established in 1990 \\
\hline $\begin{array}{l}\text { Hadley Centre for Climate } \\
\text { Prediction and Research }^{1}\end{array}$ & $\begin{array}{l}\text { www.metoffice.gov.uk/research/h } \\
\text { adleycentre/index.html }\end{array}$ & Established within the UK Met Office in 1990 \\
\hline $\begin{array}{l}\text { UK Climate Impacts Programme } \\
\text { (UKCIP) }{ }^{1}\end{array}$ & www.ukcip.org.uk/ & $\begin{array}{l}\text { Established by the Department of the } \\
\text { Environment in } 1996\end{array}$ \\
\hline $\begin{array}{l}\text { Tyndall Centre for Climate } \\
\text { Change Research }^{1}\end{array}$ & www.tyndall.ac.uk/ & $\begin{array}{l}\text { Established at the University of East Anglia in } \\
2000 \text {, }\end{array}$ \\
\hline The Carbon Trust $^{1}$ & www.carbontrust.co.uk/default.ct & $\begin{array}{l}\text { Established in } 2001 \text { by the Departments of the } \\
\text { Environment and Trade and Industry }\end{array}$ \\
\hline European Environment Agency & $\begin{array}{l}\text { ec.europa.eu/environment/climat/ } \\
\text { home_en.htm }\end{array}$ & $\begin{array}{l}\text { Climate change scenarios for } 25 \text { EU countries and } \\
\text { other relevant data sets }\end{array}$ \\
\hline Various organisations & $\begin{array}{l}\text { www.climatehotmap.org/impacts/ } \\
\text { index.html }\end{array}$ & $\begin{array}{l}\text { Mainly reports impacts but some information on } \\
\text { regional climate changes }\end{array}$ \\
\hline $\begin{array}{l}\text { Canadian Climate Impacts and } \\
\text { Scenarios project }\end{array}$ & $\begin{array}{l}\text { http://www.cics.uvic.ca/s } \\
\text { cenarios/ }\end{array}$ & Project from 1999 to 2004. \\
\hline $\begin{array}{l}\text { CSIRO Marine and Atmospheric } \\
\text { Research }\end{array}$ & $\begin{array}{l}\text { http://www.dar.csiro.au/impacts/f } \\
\text { uture.html }\end{array}$ & $\begin{array}{l}\text { Regional climate change projections for various } \\
\text { states }\end{array}$ \\
\hline $\begin{array}{l}\text { Australian Government Burean } \\
\text { of meterology }\end{array}$ & $\begin{array}{l}\text { http://www.bom.gov.au/silo/prod } \\
\text { ucts/cli_chg/ }\end{array}$ & $\begin{array}{l}\text { Maps showing trends in rainfall, temperature and } \\
\text { other climate data }\end{array}$ \\
\hline Climate Institute & $\begin{array}{l}\text { http://www.climate.org/climate_ } \\
\text { main.shtml }\end{array}$ & US site with information on impacts around world \\
\hline
\end{tabular}

Although longer-term cooling of the United Kingdom resulting from a cessation of thermohaline circulation (Gulf Stream) has been postulated (Hulme 2003), shorter term effects are likely to include the following (Meehl et al. 2000): increases in summer temperature maxima and reduced mean winter temperatures; a decrease in night time temperatures that is greater than the increase in day time temperatures, thereby reducing the diurnal

$1 \quad$ Mentioned in Hulme \& Turnpenny (2004) 
range; increased atmospheric moisture contents resulting in increased intensity of precipitation events; increased storm activity and higher velocity winds. The magnitude of these effects is forecast by down-scaling from global circulation modelling (GCMs) such as those run by the Hadley Centre (Hulme \& Turnpenny 2004, Prudhomme et al. 2003). Key areas of uncertainty remain in modelling possible changes in extratropical (mid-Atlantic) and tropical storm activity; and in the Pacific climate modelling (Meehl et al., 2000). There is considerable debate regarding the preferred method of downscaling, examples of which include: dynamical downscaling, statistical downscaling and stochastic weather generators (Prudhomme et al., 2003). The possible longer term cooling resulting from the collapse of thermohaline circulation (THC) has been modelled using coupled atmosphereocean GCM models and has been shown to be sensitive to the rates of greenhouse gas forcing, but indicates a reduction in the strength of the THC . However, the collapse of the THC can be forced by injecting large amounts of fresh water into the North Atlantic (Hulme 2003).

Table 1. Outline Climate Change Scenarios across the World (from IPCC 2007b).

\begin{tabular}{|c|c|c|}
\hline Location & Headline change to climate & Impacts with potential to directly affect engineering geology \\
\hline Africa & $\begin{array}{l}\text { Higher temperatures. } \\
\text { Lower rainfall. }\end{array}$ & $\begin{array}{l}\text { Reduction in water resources. } \\
\text { Sea level rise; coastal flooding. }\end{array}$ \\
\hline Asia & Not described; warming implied. & $\begin{array}{l}\text { Glacier melt, initial increased flooding; longer term decrease in river } \\
\text { flow due to glacier recession. } \\
\text { Reduction in freshwater availability. }\end{array}$ \\
\hline $\begin{array}{l}\text { Australia and } \\
\text { New Zealand }\end{array}$ & $\begin{array}{l}\text { Reduced precipitation; increased } \\
\text { evaporation; } \\
\text { Western and southern New } \\
\text { Zealand may initially have } \\
\text { increased rainfall. }\end{array}$ & $\begin{array}{l}\text { Sea-level rise; increases in severity and frequency of storms and } \\
\text { coastal flooding. } \\
\text { Reduction in water security. }\end{array}$ \\
\hline Europe & $\begin{array}{l}\text { Variable including increased } \\
\text { storminess, more intense rainfall } \\
\text { events; increased droughts, }\end{array}$ & $\begin{array}{l}\text { Sea level rise. } \\
\text { Retreating glaciers, inland flash floods, more frequent coastal } \\
\text { flooding; increased erosion. } \\
\text { Mountainous areas will face glacier retreat. } \\
\text { Increased water stress in some regions. }\end{array}$ \\
\hline $\begin{array}{l}\text { Latin } \\
\text { America }\end{array}$ & $\begin{array}{l}\text { Increased temperature; increased } \\
\text { evaporation; changes in } \\
\text { precipitation patterns. }\end{array}$ & $\begin{array}{l}\text { Sea-level rise; increased risk of flooding in low-lying areas } \\
\text { Reduction in water resources in some regions due to disappearance of } \\
\text { glaciers and changes to precipitation. }\end{array}$ \\
\hline $\begin{array}{l}\text { North } \\
\text { America }\end{array}$ & $\begin{array}{l}\text { Variable, including increased } \\
\text { rainfall in some regions. }\end{array}$ & $\begin{array}{l}\text { Reduction in snow; increased winter flooding, and reduced summer } \\
\text { flows from western mountains. } \\
\text { Increased tropical storms. } \\
\text { Sea level rise and coastal flooding. }\end{array}$ \\
\hline $\begin{array}{l}\text { Polar } \\
\text { Regions }\end{array}$ & Not described; warming implied. & $\begin{array}{l}\text { Reductions in thickness and extent of glaciers, ice sheets, sea ice, } \\
\text { permafrost; increased coastal erosion; increased depth of permafrost. } \\
\text { Seasonal thawing, hence increased water flow. }\end{array}$ \\
\hline $\begin{array}{l}\text { Small } \\
\text { Islands }\end{array}$ & Extreme events. & $\begin{array}{l}\text { Sea level rise, inundation, storm surge, erosion, other coastal hazards. } \\
\text { Reduction in water resources. }\end{array}$ \\
\hline UK & $\begin{array}{l}\text { Hotter, drier summers; } \\
\text { milder wetter winters. }\end{array}$ & $\begin{array}{l}\text { Sea level rise; increased flood risk to coastal areas. } \\
\text { More high intensity rainfall events. }\end{array}$ \\
\hline
\end{tabular}

\section{GROUND RESPONSE TO CLIMATE CHANGE AND ITS POTENTIAL IMPACT ON ENGINEERING GEOLOGY PRACTICE}

Even brief consideration of the likely impacts of climatic change indicates a potential effect on both existing structures and future design of all forms of engineering structures including: tunnels, retaining structures, foundations and basements.. Engineering geologists will require an increased awareness of regional-scale forecasts for groundwater levels, rainfall intensity, temperature ranges and wind loadings. Also, there will need to be an increasing awareness of the extremes, for example, in some areas, groundwater levels are likely to fluctuate over a greater range and seasonality is likely to become more extreme. For existing structures, consideration will need to be given to their inability to cope with increases in the occurrence of extreme events, for example flooding as a consequence of overloading of surface water drainage schemes, many of which have been stretched to their full potential as a consequence of urban development. An additional complication is that higher energy levels during storm events will have the potential to mobilise larger sediment loads, which will further affect the capacity of drainage systems. Within the context of this paper it has not been possible to fully develop all of the potential scenarios; instead, a broad overview and indicator of the potential impacts has been 
presented with examples of more specific case studies from the literature. As a starting point, a number of potential impacts of climate change on ground response have been tabulated inTable 4.

Table 4. Some possible ground responses to climate change.

\begin{tabular}{|c|c|c|c|}
\hline Ground response & Potential impact & Examples & Consequence \\
\hline $\begin{array}{l}\text { Changes in stress } \\
\text { conditions }\end{array}$ & $\begin{array}{l}\text { Changes in material } \\
\text { properties, including } \\
\text { strength, durability and } \\
\text { permeability. }\end{array}$ & $\begin{array}{l}\text { Reduction in strength in areas with } \\
\text { higher rainfall or more intense } \\
\text { rainfall events due to changes in } \\
\text { stress conditions; increased } \\
\text { permeability and loss of durability } \\
\text { due to weathering. }\end{array}$ & $\begin{array}{l}\text { More landslides in areas with } \\
\text { increased rainfall; questioning } \\
\text { of validity of empirically } \\
\text { derived foundation design. }\end{array}$ \\
\hline $\begin{array}{l}\text { Changes in stress } \\
\text { conditions }\end{array}$ & $\begin{array}{l}\text { Fluctuations in } \\
\text { groundwater conditions. }\end{array}$ & $\begin{array}{l}\text { Greater seasonality of groundwater } \\
\text { levels, periods of intense wetting } \\
\text { and surface water ponding. }\end{array}$ & $\begin{array}{l}\text { Implications for settlement as a } \\
\text { consequence of groundwater } \\
\text { lowering; coastal instability; } \\
\text { collapse in collapsible ground; } \\
\text { increased depth of unsaturated } \\
\text { zone may open up more } \\
\text { ground gas migration } \\
\text { pathways. }\end{array}$ \\
\hline $\begin{array}{l}\text { Changes in stress } \\
\text { conditions }\end{array}$ & $\begin{array}{l}\text { Earthquake activation by } \\
\text { glaciers melting and rises } \\
\text { in sea level. }\end{array}$ & & \\
\hline $\begin{array}{l}\text { Changes in stress } \\
\text { conditions }\end{array}$ & $\begin{array}{l}\text { Continental slope failure } \\
\text { resulting from gas hydrate } \\
\text { releases. }\end{array}$ & & \\
\hline $\begin{array}{l}\text { Changes in stress } \\
\text { conditions }\end{array}$ & $\begin{array}{l}\text { Fault reactivation in } \\
\text { response to changing } \\
\text { groundwater regimes. }\end{array}$ & & \\
\hline $\begin{array}{l}\text { Weathering } \\
\text { processes }\end{array}$ & $\begin{array}{l}\text { Change in type and rate of } \\
\text { weathering. }\end{array}$ & $\begin{array}{l}\text { Greater seasonality and more } \\
\text { chemical weathering in warmer } \\
\text { /wetter areas; greater occurrence of } \\
\text { efflorescent minerals. }\end{array}$ & $\begin{array}{l}\text { Changes to weathering } \\
\text { profiles; surface collapse - for } \\
\text { example due to dissolution or } \\
\text { decalcification; potential } \\
\text { impacts on vegetation and } \\
\text { surface erosion. }\end{array}$ \\
\hline $\begin{array}{l}\text { Weathering } \\
\text { processes }\end{array}$ & $\begin{array}{l}\text { Changes in material } \\
\text { properties, including } \\
\text { strength, durability and } \\
\text { permeability. }\end{array}$ & Development of hardpans,. & \\
\hline $\begin{array}{l}\text { Weathering } \\
\text { processes }\end{array}$ & $\begin{array}{l}\text { Changes to geochemical } \\
\text { environment of } \\
\text { construction materials. }\end{array}$ & $\begin{array}{l}\text { Changing oxidation/ reduction and } \\
\mathrm{pH} \text { conditions }\end{array}$ & $\begin{array}{l}\text { Potential impact on } \\
\text { construction materials due to } \\
\text { chemical aggressiveness. }\end{array}$ \\
\hline $\begin{array}{l}\text { Weathering } \\
\text { processes }\end{array}$ & $\begin{array}{l}\text { Shrinkage problems in } \\
\text { cohesive strata. }\end{array}$ & & $\begin{array}{l}\text { Settlement of existing } \\
\text { development on spread } \\
\text { foundations, potential need for } \\
\text { deeper foundations for new } \\
\text { build. }\end{array}$ \\
\hline
\end{tabular}

These ground responses and their impacts on engineering practice are considered in the following sections.

\section{GROUND MATERIALS AND STRUCTURES}

Griffiths \& Culshaw (2004) suggested that the term ground materials covers the description and composition of rocks, whilst structures covers faults and folds. They identified two areas of importance to engineering geologists:

- understanding and estimating the behaviour of rocks in relation to changes in stress;

- $\quad$ how the chemical composition of a rock can alter its engineering behaviour.

Both of these may be impacted on by climate change (Table 4). The latter is considered under weathering (below).

Fundamental to the understanding of soil mechanics is the understanding of the behaviour of soils and rocks subject to changes in stress. Climate change is likely to result in changes to pore pressures. Under wet conditions pore pressures rise and effective stress falls. Drier localities may be subject to lower pore pressures and higher 
effective stress conditions. However, due to the anticipated increased intensity of rainfall events, even places that may be drier overall, may experience rapid increases in pore water pressure and, consequential, rapid decreases in effective stress. Table 4 incorporates a number of the potential implications of changes in stress conditions. It is noted that current approaches to foundation design rely upon empirical methods, for example, the derivation of bearing capacity factors in cohesive soil (Nc) for use in the design of spread and piled foundations, adhesion factors derived from the ratio of undrained shear strength to effective overburden pressure and angles of shearing resistance derived from standard penetration test determined N-values (Tomlinson 1995). If climate change effects significant changes in stress conditions, engineering geologists will need to give closer attention to the applicability of empirical methods to longer-term engineering solutions.

Smaller developments, typically constructed on marginal ground conditions, are most vulnerable, for example:

- structures designed to bear into sand above the water table that are subject to rising ground water levels experience settlement as a consequence of the removal of fine particles from the soil;

- settlement of structures bearing onto silts or clays, as a consequence of lowering of groundwater levels in inland areas; and

- settlement resulting from more extreme fluctuations in groundwater levels. Structures associated with infrastructure in estuarine environments could be particularly vulnerable to this type of settlement.

Ground improvement techniques (Serridge2009) are also designed using empirical techniques. These types of foundation are often used for smaller developments in ground considered unsuitable for spread foundations and, therefore, marginal for development. The empirical approaches that are adopted are modified using recognised factors of safety. Although empirical methods and factors of safety have been employed reliably for nearly a century, consideration should be given to whether design criteria need to be modified to reflect the potential uncertainty and, therefore, decreased safety factors associated with climate change. An example is the use of ground improvement techniques in estuarine environments where future rises in groundwater levels may reduce the passive resistance afforded by alluvial soils to stone columns.

As a result of flooding, particularly in urban environments, an increasing number of sites will be subject to relatively prolonged periods of ponded water. This has a potential to affect drainage systems associated with all types of structures but, in particular, retaining structures, pavements and foundations with a consequent potential decrease in the durability of existing structures and landfill sites in vulnerable areas.

\section{REGIONAL CHARACTERISTICS}

Griffiths \& Culshaw (2004) reiterated the importance of the plate tectonic paradigm in explaining regional geological characteristics and the location of earthquakes and volcanoes. Naturally unstable environments are on, or near, plate boundaries (Waltham 2002). Engineering geologists address the engineering implications of construction in earthquake zones (for example, liquefaction potential, active fault movements, landsliding, transitory, high pore-water pressures) and on the margins of volcanoes (identifying the high-risk areas, tracking paths of explosive or poisonous gases, locating lava tubes, providing routeways for evacuation, presence of interlayers). Climate change has the potential to extend unstable environments as exemplified in the examples below. Although these types of studies are in the early stages, it is important that the results are fed into predictive models to enable mitigating measures to be scheduled in those regions that may be affected.

Draining ice-dammed lakes has triggered earthquakes in Norway and Basle, Switzerland (Becker, et al., 2002). This suggests a potential for triggering of earthquakes in locations subject to very rapid increases in sea level from glacier melting. It has also been reported that 'glacial earthquakes' occur in Greenland in response to sudden movements of glaciers (Ekstrom et al., 2006). Similarly, changes in stress regimes brought about by unloading associated with glacier wasting and loading associated with rising sea levels also offer the potential to trigger fault reactivation, with consequential impacts on slope-stability.

Gunn et al. (2002) and Maslin et al. (2004) have identified the release of gas hydrates as a trigger for continental-slope failures. Gas hydrates are suspected to make a significant contribution to climate change; for example, releases of methane hydrates and consequential climatic change over the past 450000 years have been correlated with periods of continental shelf instability in the North Atlantic by Maslin et al. (2004). The hydrates comprise a solid consisting of water with methane gas, which is stable in the high pressure, low temperature conditions found in a zone that extends to a few hundred metres below the sea floor of the continental margins (Hornbach et al. 2004 and Gunn et al., 2002). The stable depth for hydrates is limited by increasing temperatures with depth and, as a consequence, a free-gas zone forms at the base of the hydrates, which are vulnerable to climate change. Hornbach et al. (2004) have suggested that the thickness of the free-gas zone is controlled by releases via fault slips through the overlying sediment. Gunn et al. (2002) have been studying the implications of 
gas-hydrate contributions to slope instability during earthquakes by designing laboratory experiments to examine how the pressure-temperature history of gas-hydrates alters the geophysical properties of the sediment column as a consequence of the disruption of metastable cements, or increased pore-pressures. Submarine instability can be significant both in the generation of tsunamis and, also, in the mobilisation of sediment and the potential for damage to cables and pipelines on the sea-bed (Forster et al. 2009).

\section{SURFACE PROCESSES AND MATERIALS}

Engineering geologists consider material properties in terms of strength, deformability, durability and permeability and the boundaries between them. Material response to climate changes can be anticipated (Table 4) and the engineering geologist should be aware of these responses. In areas with higher rainfall or more intense rainfall events, changes could include: reduction in strength and durability and changes to permeability (either increased permeability due to greater weathering and erosion, or lower permeability due to cementation as a consequence of solutes precipitating, or soil swelling). In areas where temperatures are increasing, changes could include: increased shear strength; increased durability and possible reduction in permeability due to hardpans resulting from evaporation. Engineering geology practice will need to embrace consideration of such impacts, which will vary considerably between regions and will reflect specific geological formation response to changing conditions. For example, as recharge conditions change in response to changes in precipitation and evaporation, there will be consequential changes in geochemical conditions (Table 5 and below), with consequential aggressiveness to construction materials such as concrete and steel. Another example is the growing focus on the unsaturated zone, an area of research historically left to agriculturalists and pedologists, where rising temperatures (reducing viscosity) and increased intensity of rainfall render understanding of the unsaturated zone increasingly important in a number of areas. These include: slope stability assessments, dispersed contaminants and aquifer vulnerability modelling and the understanding and protection of agricultural soils, another area that is being seen as increasingly important in the context of sustainability and urban development.

Categories considered within the following sections are:

- $\quad$ weathering and engineering soils

- floodplains and alluvium

- coastal processes

- $\quad$ inland flooding

- landslides

\section{Weathering and engineering soils}

Weathering is the breakdown and/or decomposition of rocks by physical (wind, rain, temperature changes, plants), chemical (solution, chemical changes) and biological (primarily bacteriological) processes. Table 5 lists some of the ways climate change could impact the various weathering mechanisms. Interactions between these processes (Chorley et al. 1984) will increase the complexity of the impacts. Chemical weathering accelerates in moister, warmer areas and accelerates further with increased biological activity but decreases where moisture is reduced. Clearly, an understanding of how weathering may be affected by the anticipated climate change of a region will allow predictions of likely changes to weathering profiles. This may impact on a number of processes, such as hillslope processes and aggressiveness to construction materials (Table 4).

Table 5. Some of the potential impacts of climate change on weathering processes.

\begin{tabular}{|l|l|l|l|}
\hline $\begin{array}{l}\text { Weathering } \\
\text { process }\end{array}$ & $\begin{array}{l}\text { Likely impacts of } \\
\text { temperature change }\end{array}$ & $\begin{array}{l}\text { Likely impacts of changes in } \\
\text { precipitation }\end{array}$ & Changes due to other effects \\
\hline $\begin{array}{l}\text { Thermal } \\
\text { expansion }\end{array}$ & $\begin{array}{l}\text { Increase as temperatures } \\
\text { increase (assuming diurnal } \\
\text { temperature changes } \\
\text { increase) } \\
\text { May be exacerbated by } \\
\text { increase in desert areas }\end{array}$ & & $\begin{array}{l}\text { Increased surface erosion by more } \\
\text { intense rainfall events may } \\
\text { increase potential depth of } \\
\text { weathering }\end{array}$ \\
\hline Freeze-thaw & $\begin{array}{l}\text { Decrease as temperatures } \\
\text { increase } \\
\text { Probable overall decrease }\end{array}$ & & $\begin{array}{l}\text { May be potential for increased } \\
\text { aeolian activity in areas subject to } \\
\text { wasting ice sheets if once stable air } \\
\text { masses are disrupted by } \\
\text { temperature changes }\end{array}$ \\
\hline Pressure release & & $\begin{array}{l}\text { May increase in areas where } \\
\text { climate change leads to greater }\end{array}$ \\
\hline
\end{tabular}




\begin{tabular}{|c|c|c|c|}
\hline $\begin{array}{l}\text { Weathering } \\
\text { process }\end{array}$ & $\begin{array}{l}\text { Likely impacts of } \\
\text { temperature change }\end{array}$ & $\begin{array}{l}\text { Likely impacts of changes in } \\
\text { precipitation }\end{array}$ & Changes due to other effects \\
\hline & & & $\begin{array}{l}\text { erosion. } \\
\text { There will be pressure release } \\
\text { associated with glacier wasting } \\
\text { which could ultimately result in } \\
\text { cambering in some deglaciated } \\
\text { areas }\end{array}$ \\
\hline $\begin{array}{l}\text { Hydraulic } \\
\text { action }\end{array}$ & $\begin{array}{l}\text { Increased hydraulic action in } \\
\text { areas subject to the impacts } \\
\text { of wasting glaciers. }\end{array}$ & $\begin{array}{l}\text { Increased hydraulic action in areas } \\
\text { subject to increased intensity of } \\
\text { rainfall, locally resulting in } \\
\text { increased rates of toppling failure } \\
\text { as well as surface erosion }\end{array}$ & $\begin{array}{l}\text { Increased intensity of rainfall } \\
\text { offers the potential for more } \\
\text { oxygenating conditions. Potential } \\
\text { for mobilisation of cave deposits } \\
\text { currently resisting dissolutional } \\
\text { processes }\end{array}$ \\
\hline Dissolution & $\begin{array}{l}\text { Likely increase as } \\
\text { temperatures increase }\end{array}$ & $\begin{array}{l}\text { Likely increase as precipitation } \\
\text { increase }\end{array}$ & $\begin{array}{l}\text { Increased partial pressures of } \\
\text { carbon dioxide may affect } \mathrm{pH} \text {. } \\
\text { Increased biological activity offers } \\
\text { the potential to exacerbate this } \\
\text { process. By contrast controls on } \\
\text { industrial emissions may reduce } \\
\text { atmospheric pH. }\end{array}$ \\
\hline Decalcification & & $\begin{array}{l}\text { Increased intensity of rainfall will } \\
\text { facilitate increased rates of } \\
\text { decalcification in tills, which are } \\
\text { likely to be subject to increased } \\
\text { depths of seasonal changes in } \\
\text { moisture content. }\end{array}$ & $\begin{array}{l}\text { Increased biological activity likely } \\
\text { to impact on this }\end{array}$ \\
\hline Hydrolysis & $\begin{array}{l}\text { Potential for greater impact } \\
\text { in warmer conditions }\end{array}$ & & $\begin{array}{l}\text { Increases in weathering will result } \\
\text { in greater volumes of suspended } \\
\text { sediments (clay minerals) }\end{array}$ \\
\hline Leaching & $\begin{array}{l}\text { Potential for increased } \\
\text { dissolution of salts such as } \\
\text { gypsum and of limestone } \\
\text { and tufa }\end{array}$ & & $\begin{array}{l}\text { Increases in atmospheric carbon } \\
\text { dioxide in conjunction with } \\
\text { increased biological activity will } \\
\text { encourage karst processes }\end{array}$ \\
\hline $\begin{array}{l}\text { Oxidation/ } \\
\text { reduction }\end{array}$ & & $\begin{array}{l}\text { Inland flooding may extend areas } \\
\text { of reducing conditions. Increased } \\
\text { intensity of rainfall may increase } \\
\text { depths of oxidation processes. }\end{array}$ & \\
\hline Crystallisation & $\begin{array}{l}\text { Potential for efflorescent } \\
\text { minerals to extend beyond } \\
\text { desert environments }\end{array}$ & & $\begin{array}{l}\text { If associated with periods of } \\
\text { intense rainfall will seasonally } \\
\text { impact on ground or surface water } \\
\text { quality. }\end{array}$ \\
\hline
\end{tabular}

\section{Floodplains and alluvium}

The effects of climate change on the alluvial environment already impacts on engineering geological practice. Alluvial soils and flood plains are subject to more routine flooding. Additionally, increased seasonality of groundwater levels is likely. This could result in increased rates of weathering due to physical erosion during flooding and the potential for desiccation and increased wind erosion. Increased river discharge offers the potential for undercutting and associated slope instability.

Where foundations have been constructed through organic soils, typically in the estuarine environment, consideration may need to be given to the potential mobilisation of ground gases as a consequence of changes in groundwater levels. Specific types of structure are more likely to be sensitive to these impacts, for example, warehouses and industrial buildings are common to the estuarine environment and many in the United Kingdom pre-date requirements for the incorporation of gas remedial measures.

Kim \& Yang (2009) described how fluvial wetlands can provide valuable information with respect to changes in base levels during the Holocene. In the UK many wetlands are considered to form an invaluable habitat. As climate change is likely to be associated with rising sea-levels and more extreme climatic conditions, lowland wetlands may become increasingly vulnerable to marine or estuarine inundation. At the same time, upland wetlands could be subject to wasting as a consequence of drying during the hotter summers and erosion during more extreme rainfall (and possibly also aeolian events). The advice of the engineering geologist working in 
conjunction with environmental scientists could be invaluable in designing novel mitigation measures to protect these habitats.

\section{Coastal processes}

Forecasts for sea-level rise indicate a need to address:

- $\quad$ inundation of populated areas

- coastal instability

- $\quad$ saline intrusion

Rises in sea level will result in increased pore water pressure in the coastal environment, with a potential danger to cliff stability. Coastal erosion as a consequence of isostatic readjustment along the east coast of Britain exemplifies the processes that influence cliff retreat. Associated with the coastal erosion many areas will be subject to beach erosion, thereby increasing the potential for further wave erosion. Lowland areas will be at risk of inundation with a potential for significant economic cost, for example Zhang et al. (2004) have identified that at least 100 million people live within one metre of mean sea level. Global modelling of the type reported by Nicholls et al. (1999) indicates that the populated areas most vulnerable to flooding are in the southern Mediterranean, Africa and South and Southeast Asia, where there are significant concentrations of people in delta settings. The greatest increase in flood risk is likely to occur in the Caribbean, the Indian Ocean islands and small islands in the Pacific Ocean (Nicholls et al. 1999). The effect of the relative rise in sea-level along the coast of northern Brazil has led to the changes in planning regulations described by Szlafstein, (2009). Clearly, there is a need for the engineering geologist to be included in the forecasting and mitigation strategy planning associated with rising sea levels.

\section{Inland flooding}

As a consequence of the predicted increase in the intensity of rainfall, inland flooding is likely to impact on:

- drainage basin landscapes;

- contaminant mobilisation; (below)

- $\quad$ smear zone of contamination; (below)

- $\quad$ geochemical conditions, for example repeated flooding encourages reducing conditions.

One of the roles of the engineering geologist is to understand the significance of the geology on river systems. This can be important in terms of understanding the groundwater contribution to flooding (www.bgs.ac.uk/programmes/inposerv/ip/groundwaterflooding.html) and in terms of sediment stability. The work reported by Falkowski (2009), which describes how sub-alluvial basement highs in the middle stretches of the River Vistula, Poland have been identified as bedrock highs, demonstrates how the understanding of river bed form can contribute to the understanding of the hydrology of a river This is essential to the engineering of effective flood defences. The need to understand the consequences of increased bank storage and consequential rises in pore-pressures, with the potential risk to the stability of existing river defences and foundations along estuaries and river inlets, will be one of the future demands on engineering geologists.

Drainage basin landscapes are susceptible to climate change. Arnell \& Reynard (1996) presented the results from an investigation of potential changes in river flow in twenty one catchments in Great Britain. Annual run-off was simulated to increase by more than $20 \%$, by 2050, in the wetter catchments and to decline by a similar percentage in the drier catchments. Changes in monthly flows will be greater than those in the annual flows This has implications for development within the flood plain and for catchment development. Tucker \& Slingerland (1997) used computer modelling (GOLEM) to simulate basin evolution under the action of weathering processes, hillslope transport, fluvial bedrock erosion and sediment transport. They confirmed that, aside from potential impacts on landsliding and seepage erosion, increased intensity of rainfall, especially in conjunction with a reduction in plant cover, can result in the expansion of the channel network and consequential downstream aggradation of sediment. With time, the basinal processes will equilibrate with a change in the hydrological regime. However, in the short term, there is an increased potential for inland flooding associated with the mobilisation of sediment. Although current planning requirements in the UK (Planning Policy Guidance Note 25, ODPM 2001) call for flood risk assessment to incorporate a factor of safety for climate change and potentially greater storm events, the potential for sediment mobilisation indicates that flood risk modelling in the context of climate change is actually more complex. Reference to the complexity associated with modelling has been examined by Prudhomme et al. (2003), in particular with reference to general circulation model (GCM) selection and its impact on the magnitude and frequency of return of a given frequency event. 


\section{Landslides}

Significant rainfall events commonly trigger landslides, due to increasing pore pressures as described by Forster et al. (2009), Cruden \& Martin (2009) and Thomas et al. (2009). Forster et al. (2009) noted that there are several reasons climate change can be expected to promote landsliding:

- $\quad$ increase in annual rainfall; notably several years of above average rainfall.

- $\quad$ rainfall intensity.

- $\quad$ increased coastal landsliding as a consequence of increased storm activity.

- drier summers may facilitate tension gap development in crest/ cliff top settings.

As groundwater is the most important single factor in triggering landslide events (Waltham 2002), landslides are particularly vulnerable to changes in climatic conditions. More specifically, increased rainfall intensity facilitates increases in porewater pressure, material softening, tension-gap loading and toe erosion (locally exacerbated by increased stream erosion). Potential new mechanisms and processes of slope failure in response to changing climatic conditions may be identifiable from the literature. For example, work carried out by Cammeraat et al. (2005) examined the influence of vegetation succession in mitigating landslide activity in the Alcoy Basin, Southeast Spain. This research identified that increased vegetation cover progressively limits surface processes (sheet wash and concentrated overland flow) but most failures occurred below the depth of rooting and the significant factor was the rate of transfer to the potential slip plane via macro-pores. In the context of changing climate and potential changes in vegetation this type of research is likely to become increasingly important and is exemplified by the BIONICS project (Glendinning et al. 2009). In another example of slope failure Loope et al. (1999) showed that in an Upper Cretaceous aeolian sand dune deposit in southern Mongolia, evapotranspiration during the Cretaceous climatic conditions led to calcite accumulation in a thin layer in the order of $0.5 \mathrm{~m}$ below the surface. The calcite deposit perched subsequent rainfall events and the consequential increase in pore pressure was identified as the cause of translational slides and gravity flows. This example demonstrates the benefit of revisiting the geological record to identify potential failure processes for the future and suggests the need for a data-base linking sliding processes in the geological past with palaeoclimatic conditions.

\section{CLIMATIC VARIANTS}

Waltham (2002) included semi-arid and periglacial environments under this heading. Key engineering geological considerations in arid and semi-arid environments include: drainage (gorges, wadis and lakes), erosion (including aeolian erosion), sedimentation (alluvial fans and blown sand including dunes and loess) and sabkhatype evaporites and duricrusts. In periglacial conditions they include: permafrost and solifluction with the associated problems such as subsidence, landslides, heave, scree deposits and frost shattering. Climate change is likely to extend the area of influence of these climates.

\section{GROUND INVESTIGATION}

Ground investigation techniques per se may not change greatly as a result of climate change but the focus of ground investigations may be affected. To address this, it will be necessary for desk studies to assess the potential impacts of climate change, including both regional climate change and potential ground responses. Specific areas can be identified, for example the depth to groundwater commonly will be impacted by climate change; there is a possibility that for some sites, groundwater levels will be different to those anticipated, for example, due to very dry or wet periods, which will affect the appropriate response zones for monitoring wells. Monitoring over longer time periods increasingly will be recommended to assess more fully the potential impact of climate change, which will demand increasingly rigorous methods for data storage and processing.

There is scope for more refined ground investigation associated with the areas discussed within this paper. For example, the assessment of seasonality, which demands longer term monitoring, may drive demand for improved technology. Similarly, investigation of the unsaturated zone has increased interest in the use of tension infiltrometers and the development of laboratory procedures to determine soil suction. Optical examination of large thin section samples prepared from kubiena soil samples has proved particularly successful in the understanding of glacial tills (Hart \& Rose 2001, Phillips 2006) and could also prove to be a useful technique in contributing to the understanding of material properties in the unsaturated zone. The use of radar interferometry (Culshaw et al. 2009) monitoring may be useful in studying changes in ground elevation in response to changes in groundwater levels in the estuarine environment where a significant proportion of near-surface soils are susceptible to changes in volume in response to changes in moisture content. Specialist research areas encourage the development of specialist investigatory techniques, for instance, in the assessment of the economies of ground source heat pump installation. Sanner et al. (2000a) described the development of a thermal response test developed to assess in-situ determination of thermal properties for ground heat pump design (described below). 
This test, which has been designed for the assessment for larger plant, is carried out on a borehole heat exchanger in a pilot borehole. A heat load is applied to the borehole and the resulting temperature changes of the circulating fluid measured. Similarly research of gas-hydrates has driven development of specialist high-pressure sampling techniques, as described at the Inmartech conference in The Netherlands (Rack et al. 2000). In the context of the Ocean Drilling Project, there has been considerable development of specialist site investigation equipment. Research and development continues for example, in the direction of the deep biosphere, development of a methane tool and pressure core sampling equipment, has enabled the development of new laboratory methods for testing methane hydrates (Gunn et al. 2002).

\section{DIFFICULT GROUND CONDITIONS}

Difficult ground conditions identified by Waltham (2002) include: subsidence, soft ground, cavities, rockhead relief, sinkholes, slope failure and mined ground. The following are considered particularly prone to the impacts of climate change, as described below:

- collapsible soils;shrinkable clays;soluble rocks;

- abandoned mines.

\section{Collapsible soils}

Loess, a widespread, uniformly graded (silt) aeolian deposit, laid down during cold periods associated with glaciations, is characteristic of materials referred to as collapsible soils. These are soils that are susceptible to collapse upon wetting. Recent research (Zourmpakis et al. 2006) has demonstrated poor representation of laboratory scale testing (oedometer tests) in the assessment of their field behaviour, which is better represented by combinations of geophysical and geotechnical monitoring techniques. Similar collapsible behaviour has been identified in the Thanet Beds of southeast England and other uniformly graded soils. Where strength loss occurs in response to wetted front penetration, this may be attributable to one or more of a number of processes, such as breaking of weak bonds, physical disturbance and displacement of bridging particles (also suspected in some loess deposits), or disruption of precipitates (crusts resulting from geochemical processes). The impact of increased rainfall intensity is not necessarily translated into rapid wetted front penetration, as the soil response to rainfall intensity varies considerably between soil types. However, increased intensity has the potential both to move surface material and compact the surface, thereby making it more prone to surface run-off (Statham 1977). Sub-surface processes form a significant focus for research of the vadose zone, for instance, studies of macropores and of wetting front instability resulting from air entrapment (Glass et al. 1989).

\section{Shrinkable clays.}

Clays are susceptible to changes in volume in response to changes in moisture content. Reflecting their mineralogy, some clays are more susceptible to volume change than others. A consequence of climate change is likely to be seasonal reduction in soil moisture content due to lower summer rainfall and higher temperatures. This is likely to lead to an increase in the number of cases of building damage that can be attributed to subsidence resulting from clay shrinkage (Doornkamp 1993). In the urban environment there is increased local authority interest in the impact of paving on tree root development. Generally, tree roots grow in the direction of least resistance and best access to water, air and nutrients. In areas covered by paving, low moisture contents may encourage roots to extend farther to find water, which can result in physical damage to buildings or foundations either by clay shrinkage or by physical damage by roots. Research by Roberts et al. (1980) suggested that there are limiting moisture contents, below which stromatal closure occurs. This is an area that calls for further research, for example, some consideration has been given to the management of trees in the urban environment (BRE 2004).

\section{Abandoned mines}

Experience would suggest that some of the engineering problems associated with the legacy of the past that were outlined to this session could become increasingly significant in the context of global warming. Amongst these is the potential for increased frequency of mine related, or shaft collapse (Heitfeld et al. 2009).

\section{Soluble rocks.}

Hazards associated with soluble rocks, such as limestone and gypsum, are well documented (Brooks et al. [2009], Cooper \& Waltham 1999). Dissolution rates could be affected by climate change both in terms of changing (generally increasing) temperatures and changes in the hydrological regime. Increased carbon dioxide concentrations will alter $\mathrm{pH}$ conditions. Of particular interest may be the dissolution and precipitation of calcium carbonate and calcium sulphate (gypsum). Aside from the potential physical changes resulting from such 
reactions, associated $\mathrm{pH}$ changes affect aggressiveness to construction materials such as concrete and steel. Similarly, localised ponding could encourage the development of reducing conditions. Another example is the potential for increased dissolution of gypsum due to the greater intensity in rainfall (and also as a consequence of drainage problems in urban environments), resulting in dissolution in areas that had previously been dry (Forster \& Culshaw 2004).

\section{CONTAMINANT TRANSPORT PROCESSES}

In contrast with drier areas (without extreme rainfall events), where less contaminant migration might be anticipated, in areas where there is more water (whether in total or at intervals as a result of extreme events) consideration should be given to contaminant mobilisation and spreading, which could occur in response to a number of mechanisms:

- $\quad$ increased flooding and, therefore, surface flow;

- $\quad$ increased sub-surface flow;

- $\quad$ increased transport of contaminants from vadose to saturated zone;

- $\quad$ increased migration within the saturated zone.

The "smear zone" is the area around the water table over which contamination from the light non-aqueous phase liquid (LNAPL) contamination can migrate as a result of fluctuations in the level of the water table. Contamination is present as immiscible product or as residual saturation within the capillary zone (Consultants in Environmental Sciences Ltd 2000). The extent of the smear zone is a function of the range of variation of the water table. In areas, where climate change is likely to result in drier summers and wetter winters, the extent of the smear zone is expected to increase.

\section{THE ROLE OF ENGINEERING GEOLOGY IN CLIMATE CHANGE MITIGATION AND ADAPTATION}

In conjunction with developing understanding of the impacts of climate change on engineering geology, as a community, engineering geologists have a responsibility to investigate how engineering geology can contribute to the mitigation of, and adaption to, climate change. Some possibilities are listed in Table 6 and expanded below.

Table 6. Possible areas where engineering geologists can contribute to climate change mitigation.

\begin{tabular}{|l|l|l|}
\hline \multirow{3}{*}{ Mitigation } & Area of contribution & Issues addressed \\
\cline { 2 - 3 } & Ground source heat pumps & Non-fossil fuel energy \\
\cline { 2 - 3 } & Carbon sequestration & Prevention of carbon entering atmosphere \\
\cline { 2 - 3 } & Reduce Reuse Recycle & $\begin{array}{l}\text { Including:, use of waste products for building and } \\
\text { aggregates which result in a reduction in the use of } \\
\text { resources (and hence energy) }\end{array}$ \\
\hline Adaptation & $\begin{array}{l}\text { Sustainable Urban Drainage Systems } \\
\text { Water Supply } \\
\text { Policy }\end{array}$ & $\begin{array}{l}\text { Water resources } \\
\text { Water resources }\end{array}$ \\
\hline
\end{tabular}

\section{GROUND SOURCE HEAT PUMPS}

Ground source heat pump (GSHP) systems utilise the sub-surface as a heat reservoir to supply energy without using fossil fuels. A ground heat pump is a closed-loop compression-type refrigeration system comprising a cooling heat exchanger (evaporator), placed beneath the ground surface, linked to a heating radiator (compressor) placed where the generated heat is extracted from the ground. The heat exchanger is designed as either a vertical loop (borehole heat exchanger), or a horizontal loop. Alternatively, an open loop system fed by groundwater from a well can be used. Whilst these systems are relatively common in America and in Europe, currently they are not widely known in the United Kingdom (Gale 2005); accordingly one of the roles of the engineering geologist is in knowledge transfer. There have been recent technological developments of the systems that are available, including the design of thermally-enhanced grouting materials, to minimise heat loss to vertical loop systems installed in boreholes (Sanner, et al., 2000b). The initial installation costs are relatively high. However, they have relatively low running costs. A detailed understanding of the ground conditions is necessary to provide advice on the viability of installation. The British Geological Survey offers web-based reporting products, to provide geological information and physical and thermal data. Neither the geology nor the 
engineering geology (except perhaps some types of unstable ground) preclude the use of GSHP. However, ground conditions affect the:

- $\quad$ heating and/or cooling potential of the ground;

- $\quad$ installation of the system (and therefore costs) for example, drilling or trenching methods.

Some of the ways ground conditions influence GSHP, largely based on Gale (2005), are tabulated below.

Table 7. Influence of ground conditions on GSHP.

\begin{tabular}{|c|c|c|}
\hline \multicolumn{2}{|c|}{ Ground characteristic } & \multirow[b]{2}{*}{$\begin{array}{l}\text { Significance } \\
\text { Strength affects drilling/trenching methods } \\
\text { Important for horizontal loop system } \\
\text { If drift is less than } 1.5 \text { m thick it may not be possible to install a } \\
\text { horizontal ground loop. Large boulders have the same effect. } \\
\text { For vertical system, a thick layer of drift may increase drilling } \\
\text { costs }\end{array}$} \\
\hline Drift & $\begin{array}{l}\text { Geotechnical properties } \\
\text { Thermal properties } \\
\text { Thickness }\end{array}$ & \\
\hline $\begin{array}{l}\text { Ground } \\
\text { instability }\end{array}$ & $\begin{array}{l}\text { Landfill sites } \\
\text { Quarries/ infilled land } \\
\text { Brine-related subsidence } \\
\text { Landslides } \\
\text { Ground dissolution } \\
\text { Compressible ground } \\
\text { Running sand } \\
\text { Collapsible ground } \\
\text { Shrink/swell clays } \\
\text { Natural cavities } \\
\text { Mining subsidence/cavities }\end{array}$ & $\begin{array}{l}\text { Any ground stability issue would need to be taken into account in } \\
\text { the design of the system and, depending on the severity of the } \\
\text { ground instability hazard, may preclude installation }\end{array}$ \\
\hline $\begin{array}{l}\text { Soil } \\
\text { characteristics }\end{array}$ & $\begin{array}{l}\text { Sand, silt or clay } \\
\text { Moisture content } \\
\text { Soil density }\end{array}$ & $\begin{array}{l}\text { More efficient in silt and clay } \\
\text { Dry soil traps more air so lower thermal conductivity } \\
\text { Loose soil traps more air so lower thermal conductivity }\end{array}$ \\
\hline Solid geology & $\begin{array}{l}\text { Geotechnical properties } \\
\text { Thermal properties } \\
\text { Thickness of weathering zone } \\
\text { Thermal conductivity } \\
\text { Thermal properties }\end{array}$ & $\begin{array}{l}\text { Strength affects drilling/trenching methods } \\
\text { Important for horizontal loop system } \\
\text { Affects drilling methods } \\
\text { Thermal conductivity is higher in rocks than soil } \\
\text { Important for vertical borehole }\end{array}$ \\
\hline Groundwater & $\begin{array}{l}\text { Artesian risk } \\
\text { Amount of groundwater flow } \\
\text { Flow direction }\end{array}$ & $\begin{array}{l}\text { Required for open loop systems } \\
\text { Affects the design; shallow ground may be helpful for a vertical } \\
\text { open loop system. } \\
\text { However, for a horizontal system shallow groundwater may mean } \\
\text { dewatering of the excavation is required } \\
\text { Needs to be assessed prior to drilling } \\
\text { Generally flow improves heat exchange and may also prolong life } \\
\text { of system } \\
\text { Downwards flow may reduce temperatures }\end{array}$ \\
\hline $\begin{array}{l}\text { Thermal } \\
\text { properties }\end{array}$ & $\begin{array}{l}\text { Ground temperature } \\
\text { Thermal diffusivity } \\
\text { Thermal conductivity }\end{array}$ & $\begin{array}{l}\text { Heat transfer driven by difference in temperature between ground } \\
\text { and circulating fluid } \\
\text { Controls transmission of annual temperature cycle at ground level } \\
\text { into the sub-surface to depths of around } 15 \mathrm{~m} \\
\text { Affected by moisture content and soil density } \\
\text { Higher in rocks than soil } \\
\text { Controls temperature profile below around } 15 \mathrm{~m} \text {, together with } \\
\text { heat flux and heat flow via groundwater }\end{array}$ \\
\hline Other & Presence of underground workings & $\begin{array}{l}\text { Flooded coal mine workings can up used as source for open or } \\
\text { closed loop systems } \\
\text { Also affects drilling methods. }\end{array}$ \\
\hline
\end{tabular}

\section{CARBON SEQUESTRATION}

Carbon sequestration is the removal of carbon dioxide from the atmosphere coupled with long-term storage. The term may be used to include natural carbon sinks, such as forests and oceans, but in the context of engineering geology is used to describe the capture and long-term storage of carbon dioxide before it is emitted into the atmosphere. In the short term, carbon sequestration is being developed to separate $\mathrm{CO}_{2}$ from other power station 
emissions followed by the pumping of $\mathrm{CO}_{2}$ underground. In the longer term, this could be extended to capture $\mathrm{CO}_{2}$ from high carbon producing industries such as cement, ammonia and iron manufacture (IPCC 2007a). Currently, carbon dioxide sequestration forms a significant focus for engineering geological research. Essential in the assessment of site suitability for carbon dioxide storage is an understanding of the physical properties of carbon dioxide. Of particular note is the increase in carbon dioxide density in a depth range in the order of 500 to $1000 \mathrm{~m}$, depending on the geothermal conditions. Suitable geological conditions comprise: areas of sufficient capacity (a function of porosity and thickness) and injectivity (permeability); presence of an extensive low permeability layer above the formation to prevent leakage (for example, shale, salt, anhydrite beds and a stable geological environment (IPCC 2005). Holloway (2005) suggested that the main concepts for underground storage sites for carbon dioxide fall into four main categories: natural and man-made caverns, unused porous and permeable reservoir rocks, depleted oil and gas fields and coal beds. The British Geological Survey has been involved in underground sequestration of carbon dioxide (Holloway 2005), focused on the Sleipner West gas field, a sandstone reservoir, in the Norwegian sector of the North Sea, where in the order of one million ton of carbon dioxide per year are being stored underground (Holloway 2005). In some settings there is a risk that subsurface storage of $\mathrm{CO}_{2}$ could result in fault reactivation, hence, measurement of in situ stresses and evaluation of fault stability are required (Streit \& Hillis 2004).

Holloway (2005) suggested that for this technology to spread to industrial plant and make a global impact on global carbon dioxide emissions there are a number of major issues that need to be addressed including: methods of capture, demonstration of safety and security and public acceptability. There are a number of other research directions associated with carbon storage and capture, including: promoting the understanding of the physical properties and underground migration of carbon dioxide, assessments of host rock/ carbon dioxide interactions, particularly in the context of carbonate stability, developing techniques for assessing and modelling site suitability and monitoring carbon dioxide injection and monitoring. In the context of new sites, aspects such as in situ stress conditions, geothermal gradients, receiving strata permeability and the identification of traps and assessments of seismic stability will require investigation, suggesting the potential for the development of new site investigation and monitoring techniques.

\section{REDUCE, REUSE, RECYCLE}

As in many fields, engineering geologists can look to contribute to sustainability by investigating (Table 8):

- reducing inputs of materials;

- reusing materials;

- recycling.

Table 8. Engineering geology and reduce, reuse, recycle.

\begin{tabular}{|l|l|}
\hline Action & Technique \\
\hline Reduce & $\begin{array}{l}\text { Reducing use of concrete (a contributor of } \mathrm{CO}_{2} \text { ) by better design or development of alternative } \\
\text { materials, for example reuse of concrete aggregates in foundations ZICER Building, University } \\
\text { of East Anglia, (BRE 2003) }\end{array}$ \\
\hline Reuse & $\begin{array}{l}\text { Design to maximise reuse of materials on or close to site, e.g. balancing cut and fill operations for } \\
\text { transport (which has long been routine) }\end{array}$ \\
\hline Reuse, recycle & Development of techniques to maximise materials reuse from deconstruction \\
\hline Reduce, reuse & $\begin{array}{l}\text { Remediation selection to take account of likely reuse of generated materials, for example, soil } \\
\text { washing produces materials of various grades; some can be reused anywhere on site; some can be } \\
\text { reused in less sensitive locations }\end{array}$ \\
\hline Reuse, recycle & $\begin{array}{l}\text { Increased use of various waste products with a view to reuse as aggregate for selected purposes, } \\
\text { efor example, colliery spoil, pulversised fuel ash, incinerator ash, slate and china-clay wastes }\end{array}$ \\
\hline Recycle & $\begin{array}{l}\text { Evaluating tyres (and other waste products) in respect of contamination potential so that they may } \\
\text { be confidently used (or rejected) as building materials }\end{array}$ \\
\hline Reduce & $\begin{array}{l}\text { Better data analysis will increase the efficiency of site investigation, for example, geologist on } \\
\text { site; use of GIS, modelling tools. Benefits include: reduction in amount of site investigation, less } \\
\text { conservative design for buildings and reduction in area requiring geotechnical or contamination } \\
\text { remediation }\end{array}$ \\
\hline Reduce & Use of risk assessment to reduce size of areas requiring remediation. \\
\hline
\end{tabular}

\section{SUSTAINABLE URBAN DRAINAGE SYSTEMS (SUDS)}

One impact of climate change is that many areas, particularly in the urban environment, will suffer from an increased number of high intensity rainfall events which increase the risk of flooding. A method of mitigating 
against flooding is the use of Sustainable Urban Drainage Systems (SUDs), designed to return surface water to the natural drainage system close to the source and reduce, or prevent, large volumes of water being released into the artificial drainage system. SUDs also incorporate measures to remove pollutants. Design in accordance with SUDs (Woods Ballard et al. 2007) may be specified by building control to increase surface water storage in zones of potential groundwater flooding (ODPM, 2001), or simply for sustainable use of surface water in an area of newer building development and new road construction. In the context of flood-plain storage, SUDs ensure the retention of surface water during periods of flooding, followed by later release, thereby reducing flood plain surface water damage associated with a given flood event.

In areas where drier periods are anticipated, SUDs are designed to increase water recharge in the wetter parts of the year thereby contributing to the underground water resource. SUDs options include (Wilson et al. 2004; Woods Ballard et al., 2007):

- Measures to reduce surface water volume, e.g. rainwater harvesting, green roofs

- Measures to encourage infiltration into the ground, e.g. infiltration trenches; filter strips and swales

- $\quad$ Provision for temporary water storage, e.g. basins and ponds

- $\quad$ Flood impact management, e.g. sacrificial areas for flooding

Table 9 details some of the ways ground conditions influence SUDs and hence ways in which engineering geologists may become involved.

Table 9. Influence of ground conditions on SUDs

\begin{tabular}{|l|l|}
\hline $\begin{array}{l}\text { Ground } \\
\text { characteristic }\end{array}$ & Significance \\
\hline Permeability & $\begin{array}{l}\text { Drainage via features such as filter strips and swales requires sufficient ground } \\
\text { permeability to allow infiltration of the expected run-off. In lower permeability } \\
\text { materials a different approach e.g. constructed higher permeability materials is } \\
\text { required. }\end{array}$ \\
\hline Hydrogeology & $\begin{array}{l}\text { Affects the amount of water that can be released into the ground without adverse } \\
\text { impact. For example, depth to groundwater, existing flow regime; existing water } \\
\text { quality; presence of rising groundwater; groundwater abstractions }\end{array}$ \\
\hline $\begin{array}{l}\text { Groundwater } \\
\text { vulnerability }\end{array}$ & \begin{tabular}{l} 
Impact of potential pollutants \\
\hline Ground stability
\end{tabular} \\
$\begin{array}{l}\text { Ponds, basins and swales may be vulnerable to slope instability in certain materials; } \\
\text { Release of water into the ground via infiltration measures could also cause ground } \\
\text { instability } \\
\text { Silty materials may be vulnerable to piping }\end{array}$ \\
\hline $\begin{array}{l}\text { Potential adverse impact on foundations if infiltration measures are located close to } \\
\text { structures }\end{array}$ \\
\hline Pollution & $\begin{array}{l}\text { On brownfield sites, prevention of infiltration may be important to prevent mobilisation } \\
\text { of contamination } \\
\text { Leakage from swales may concentrate diffuse contaminants, such as phosphates and } \\
\text { pesticides }\end{array}$ \\
\hline
\end{tabular}

\section{WATER SUPPLY}

.Climate change is likely to lead to a reduction in groundwater resources, for reasons such as:

- Increased drought.

- $\quad$ Decreased snow melt.

- $\quad$ Salinisation due to rising aquifers.

- $\quad$ Potential for increased contamination of supplies due to intense rainfall events.

In locations that experience seasonal shifts groundwater resources may be reduced if the highest rates of precipitation occur during periods of higher temperatures and hence increased evapo-transpiration. Groundwater resources are increasingly vulnerable to contamination both as a consequence of increasing global industrialisation and as a consequence of climate change. For example, rising sea levels, in conjunction with falling inland groundwater levels could potentially result in increased saline intrusion in coastal areas. This has been recognised in the identification of the River Arun in West Sussex, England as a susceptible location to the impacts of climate change in South East England (Wade et al. 1999). 


\section{POLICY}

In developing methodologies for mitigating the impacts of climate change the engineering geologist should have an influence on policy development. UNEP (2007) acknowledges the importance of effective policy responses to climate change and other environmental problems. "The only way to address these harder problems requires moving the environment from the periphery to the core of decision-making: environment for development, not development to the detriment of environment." Szlafsztein (2009) has shown how planning regulation has been in northern Brazil in response to rising sea-levels. Similarly, UK planning guidance requires consideration of climate change, for example, in the context of Planning Policy Guidance 25 (ODPM 2001) and its replacement Planning Policy Statement 25 (Communities and Local Government 2006a). More broadly, the consultation document Planning policy statement: Planning and Climate Change Supplement to Planning Policy Statement 1 (Communities and Local Government 2006b) embraces the need to consider climate change in the context of reducing emissions and the need to adapt to unavoidable consequences of climate change. There is a potential for the use of maps of engineering geology to underpin planning decisions that are potentially influenced by climate change.

Issues raised in this paper suggest a need to further consider climate change in the context of UK engineering guidance on:

- slope stability;extension of existing restrictions on floodplain development;re-assessment of foundations in shrinkable soils;

- groundwater protection;

- $\quad$ Eurocode 7 .

\section{CONCLUSIONS}

The few papers that dealt with climate change in the Legacy of the past and future climate change Session of the $10^{\text {th }}$ IAEG Congress highlighted a range of issues that engineering geologists will have to address in order to adapt to climate change. This paper has raised further issues, in the context of changes in stress conditions and weathering processes. As with other areas of science, managing climate change requires increased collaboration, both in terms of understanding processes and engineering procedures for mitigation. The relative absence of information available to the engineering geological community suggests that there is a need for knowledge transfer and it is hoped that this paper has gone some way to raise the issues and provide routes to accessible information. In particular, consideration has been given to the modelling of climate change,, including GCM and methods of down-scaling, which are important in understanding the likely change scenarios for individual countries or regions and are required to relate the likely engineering geological impacts of climate change. Current research is largely focused on mitigation and adaption measures, such as carbon sequestration, methane hydrates and sustainable urban drainage systems (SUDS). The systematic approach to assessing some of the likely impacts of climate change on existing practice has highlighted the potential for research in areas that are currently largely addressed through empirical design.

\section{Acknowledgements}

This contribution has benefited from constructive comments made by Geoffrey Jago (East Midlands Regional Group of the Geological Society) and Paul Nathanail (Land Quality Management). This paper is published with the permission of the Executive Director of the British Geological Survey (NERC).

\section{REFERENCES}

ARNELL, N. W. \& REYNARD, N. S. 1996. The effects of climate change due to global warming on river flows in Great Britain. Journal of Hydrology, 183, 3-4, 397-424.

BACASTOW, R. B., KEELING, C. D. \& WHORF, T. P. 1985. Seasonal amplitude increase in atmospheric $\mathrm{CO}_{2}$ concentration at Mauna Loa, Hawaii, 1959-82. Journal of Geophysical Research, 90 (D6): 10529 - 19540.

BARTON, M. E. 2009. Do coastal cities have a sustainable long-term future? In: Culshaw, M. G., Reeves, H. J., Jefferson, I. \& Spink, T. W. (eds). Engineering geology for tomorrow's cities. Geological Society, London, Engineering Geology Special Publication **, (on CD-ROM insert, Paper 263).

BECKER, A., DAVENPORT, C. A. \& GIARDINI, D. 2002. Palaeoseismicity studies on end-Pleistocene and Holocene lake deposits around Basle, Switzerland. Geophysical Journal International, 149, 3, 659-678.

BIRCH, G. \& WARREN, C. 2009. Technical developments in the monitoring of the Folkestone Warren landslide complex. In: Culshaw M. G., Reeves H. J., Jefferson I. \& Spink T. W. (eds). Engineering geology for 
tomorrow's cities. Geological Society, London, Engineering Geology Special Publication ** , (on CD-ROM Paper 78).

BRITISH GEOLOGICAL SURVEY. 2007. Greenhouse or snowball? Past and future climates, Earthwise Issue 24, British Geological Survey, Keyworth, 42p.

BROOKS, T. G., O’RIORDAN, N.J., BIRD, J.F., STIRLING, R. \& BILLINGTON, D. 2009. Stabilisation of abandoned salt mines in North West England. In: Culshaw M. G., Reeves H. J., Jefferson I. \& Spink T. W. (eds). Engineering geology for tomorrow's cities. Geological Society, London, Engineering Geology Special Publication **, (on CD-ROM Paper 781).

BRE.2003. The UK construction industry: progress towards more sustainable construction 2000 - 2003. The Sustainable Construction Task Group. Building Research Establishment, Watford.

BRE. 2004. Controlling water use of trees to alleviate subsidence risk. Report for the LINK Consortium for Horticulture LINK Project No. 212. Building Research Establishment, Watford. 18p.

CAMMERAAT, E., VAN BEEK, R. \& KOOIJMAN, A. 2005. Vegetation succession and its consequences for slope stability in SE Spain. Plant and Soil, 278, 1-2, 135-147.

CHORLEY, R. J., SCHUMM, S. A. \& SUGDEN D. E. 1984. Geomorphology. Methuen Publ;ishing Ltd., London. 605p.

CLARKE, B. G., WELFORD, M. \& HUGHES, D. B. 2009. The threat of abandoned mines on the stability of urban areas. In: Culshaw M. G., Reeves H. J., Jefferson I. \& Spink T. W. (eds). Engineering geology for tomorrow's cities. Geological Society, London, Engineering Geology Special Publication **, (on CD-ROM Paper 379).

COMMUNITIES AND LOCAL GOVERNMENT. 2006a. Planning Policy Statement 25: Development and Flood risk. The Stationery Office, London.

COMMUNITIES AND LOCAL GOVERNMENT 2006b Consultation Planning Policy Statement: Planning and Climate Change Supplement to Planning Policy Statement 1. The Stationery Office, London.

CONSULTANTS IN ENVIRONMENTAL SCIENCES LTD. (CES). 2000. Guidance for the safe development of housing on land affected by contamination. Environment Agency, Bristol. 86pp.

COOPER, A. H. \& WALTHAM, A. C. 1999. Subsidence caused by gypsum dissolution at Ripon, North Yorkshire. Quarterly Journal of Engineering Geology and Hydrogeology. 32, 305-310.

CRUDEN, D. M. \& MARTIN, C. D. 2009. A century of risk management at the Frank Slide, Canada. In: Culshaw M. G., Reeves H. J., Jefferson I. \& Spink T. W. (eds). Engineering geology for tomorrow's cities. Geological Society, London, Engineering Geology Special Publication **, (on CD-ROM Paper 772).

CULSHAW, M., TRAGHEIM, D., BATESON, L. \& DONNELLY, L. 2009. Measurement of ground movements in Stoke-on-Trent (UK) using radar interferometry. In: Culshaw M. G., Reeves H. J., Jefferson I. \& Spink T. W. (eds). Engineering geology for tomorrow's cities. Geological Society, London, Engineering Geology Special Publication **, (on CD-ROM Paper 125).

DEVLEESCHOUWER, X. 2009. GIS management of abandoned colliery in the Mons basin (Belgium): a case study at Levant de Mons. In: Culshaw M. G., Reeves H. J., Jefferson I. \& Spink T. W. (eds). Engineering geology for tomorrow's cities. Geological Society, London, Engineering Geology Special Publication **, (on CD-ROM Paper 423).

DEVLEESCHOUWER, X., MULLARD, C. \& GOEMAERE, E. 2009. Management of abandoned slate and coticule underground quarries by means of GIS, Vielsalm, Belgium. In: Culshaw M. G., Reeves H. J., Jefferson I. \& Spink T. W. (eds). Engineering geology for tomorrow's cities. Geological Society, London, Engineering Geology Special Publication **, (on CD-ROM Paper 413).

DIXON, N., DIJKSTRA, T., FORSTER, A. \& CONNELL, R. 2009 Climate change impact forecasting for slopes (CLIFFS) in the built environment. In: Culshaw M. G., Reeves H. J., Jefferson I. \& Spink T. W. (eds). Engineering geology for tomorrow's cities. Geological Society, London, Engineering Geology Special Publication **, (on CD-ROM Paper 528).

DONNELLY, L. J., CULSHAW, M. G., BELL, F. G. \& TRAGHEIM, D. 2009. Ground deformation caused by fault reactivation: some examples. In: Culshaw M. G., Reeves H. J., Jefferson I. \& Spink T. W. (eds). Engineering geology for tomorrow's cities. Geological Society, London, Engineering Geology Special Publication **, (on CD-ROM Paper 111).

DOORNKAMP, J. C. 1993. Clay shrinkage induced subsidence. The Geographical Journal, 159, 2, 196-202.

EKSTROM, G., NETTLES, M. \& TSAI, V. C. 2006. Seasonality and increasing frequency of Greenland glacial earthquakes. Science, 311, 1756-1758.

FALKOWSKI, T. 2009. Alluvial basement influence on channel processes in urban reaches of the middle Vistula River, Poland. In: Culshaw M. G., Reeves H. J., Jefferson I. \& Spink T. W. (eds). Engineering geology for tomorrow's cities. Geological Society, London, Engineering Geology Special Publication **, (on CD-ROM Paper 471). 
FERREIRA, C. J., FERNANDEZ-DA-SILVA, P. C., BROLLO, M. J. \& CRIPPS, J. C. 2009. Dereliction problems from exploitation of residual soil and ornamental stone at Ubatuba, São Paulo State, Brazil. In: Culshaw M. G., Reeves H. J., Jefferson I. \& Spink T. W. (eds). Engineering geology for tomorrow's cities. Geological Society, London, Engineering Geology Special Publication **, (on CD-ROM Paper 146).

FOOKES, P. \& LEE, M. E. 2007. Climate variation: a simple geological perspective. Geology Today, 23, 2, 6673.

FORSTER, A. \& CULSHAW, M. G. 2004. Implications of climate change for hazardous ground conditions in the UK. Geology Today, 20, 61-67.

FORSTER, A., CULSHAW, M. G., WILDMAN, G. \& HARRISON, M. 2009. Implications of climate change for urban areas in the UK from an engineering geological perspective. In: Culshaw M. G., Reeves H. J., Jefferson I. \& Spink T. W. (eds). Engineering geology for tomorrow's cities. Geological Society, London, Engineering Geology Special Publication **, (on CD-ROM Paper 246).

GALE, I. N. 2005. Ground source heat pumps: development of GeoReports for potential site characterisation, issue 1.2. British Geological Survey Commissioned Report CR/05/217N. 24p.

GENSKE, D.D. AND RUFF, A. Expanding cities, shrinking cities, sustainable cities: challenges, opportunities and examples. In: Culshaw M. G., Reeves H. J., Jefferson I. \& Spink T. (eds) Engineering Geology for Tomorrow's Cities. Geological Society, London, Engineering Geology Special Publications , CD paper number 82, in press.

GLASS, R. J., CANN, S., KING, J., BAILY, N., PARLANGE, J-Y. AN\&D SEENHUIS, T. S. 1990. Wetting front instability in unsaturated porous media: a three-dimensional study in initially dry sand. Transport in Porous Media, 5, 3, 247-268.

GLENDINNING, S., ROUAINIA, M., HUGHES, P. \& DAVIES, O. 2009. In: Culshaw M. G., Reeves H. J., Jefferson I. \& Spink T. W. (eds). Engineering geology for tomorrow's cities. Geological Society, London, Engineering Geology Special Publication **, (on CD-ROM Paper 348).

GÖRÖG, P. \& TÖRÖK, A. 2009. Stability problems of abandoned clay pits in Budapest. In: Culshaw M. G., Reeves H. J., Jefferson I. \& Spink T. W. (eds). Engineering geology for tomorrow's cities. Geological Society, London, Engineering Geology Special Publication **, (on CD-ROM Paper 295).

GRIFFITHS, H. I. \& PEDLEY, H. M. 1995. Did changes in late Last Glacial and early Holocene atmospheric $\mathrm{CO}_{2}$ concentrations control rates of tufa precipitation? The Holocene, 5, 2, 238-242.

GRIFFITHS, J. S. \& CULSHAW, M. G. 2004. Seeking the research frontiers for UK engineering geology. Quarterly Journal of Engineering Geology and Hydrogeology, 37, 317-325.

GUNN, D. A., NELDER, L. M., ROCHELlE, C. A., BATEMAN, K., JACKSON, P. D., LOVELL, M. A., HOBBS, P. R. N., LONG, D., REES, J. G., SCHULTHEISS, P., ROBERTS, J. \& FRANCIS, T. 2002. Towards improved ground models for slope instability evaluations through better characterization of sediment-hosted gashydrates. Terra Nova, 14, No. 6, 443-451.

HALL, J., YOUNGER, P. \& GLENDENNING, S. 2009. Is minewater a source of hazardous gas? In: Culshaw M. G., Reeves H. J., Jefferson I. \& Spink T. W. (eds). Engineering geology for tomorrow's cities. Geological Society, London, Engineering Geology Special Publication ** , (on CD-ROM Paper 349).

HART, J. \& ROSE, J. 2001. Approaches to the study of glacier bed deformation. Quaternary International, 86, 45-58.

HATHEWAY, A. W. \& DOYLE, B. C. 2009. Technical history of the town gas plants of the British Isles. In: Culshaw M. G., Reeves H. J., Jefferson I. \& Spink T. W. (eds). Engineering geology for tomorrow's cities. Geological Society, London, Engineering Geology Special Publication ** , (on CD-ROM Paper 564).

HEITFELD, M., KLUNKER, J., MAINZ, M. \& SCHETELIG, K. 2009. Risk of collapse features from near surface cavities in old mining cities. In: Culshaw M. G., Reeves H. J., Jefferson I. \& Spink T. W. (eds). Engineering geology for tomorrow's cities. Geological Society, London, Engineering Geology Special Publication **, (on CD-ROM Paper 461).

HOLLOWAY, S. 2005. Underground sequestration of carbon dioxide - a viable greenhouse gas mitigation option. Energy, 30, 2318-2333.

HORNBACH, M. J., SAFFER, D. M. \& HOLBROOK, S. W. 2004. Critically pressured free-gas reservoirs below gas-hydrate provinces. Letters to Nature. Nature, 427, 142-4.

HULME, M. 2003. Abrupt climate change: can society cope? Philosophical Transactions of the Royal Society London A 361, 2001-2021.

HULME, M. \& TURNPENNY, J. 2004. Understanding and managing climate change: the UK experience. The Geographical Journal, 170, 2, $105-115$.

IPCC. 2005. IPCC Special Report on carbon dioxide capture and storage. Metz, B., Davidson, O., de Coninck, H., Loos, M. and Meyer, L. (eds.) Prepared by Working Group III of the Intergovernmental Panel on Climate Change. Cambridge University Press, Cambridge, UK, 442p. 
IPCC 2007a. Climate change 2007: the physical science basis. Solomon, S. Qin, D. Manning, M. Chen, Z. Marquis, M. Averyt, K. B.Tignor, M. \& Miller, H. L. (eds). Contribution of Working Group I to the Fourth Assessment Report of the Intergovernmental Panel on Climate Change. . Cambridge University Press, Cambridge, U.K.

IPCC. 2007b. Climate change 2007. Impacts, adaptation and vulnerability. Parry, M., Canziani, O., Palutikof, J., van der Linden, P. \& Hanson, C. (eds). Contribution of Working Group II to the Fourth Assessment Report of the Intergovernmental Panel on Climate Change. Cambridge University Press, Cambridge, UK.

KIM, J. Y. \& YANG, D. Y. 2009. Fluvial wetland formations in South Korea. In: Culshaw M. G., Reeves H. J., Jefferson I. \& Spink T. W. (eds). Engineering geology for tomorrow's cities. Geological Society, London, Engineering Geology Special Publication **, (on CD-ROM Paper 386).

KONSTANTOPOULOU, G. \& HAYIOU, E. 2009. Rehabilitation of abandoned public quarries in Greece - a methodological approach. In: Culshaw M. G., Reeves H. J., Jefferson I. \& Spink T. W. (eds). Engineering geology for tomorrow's cities. Geological Society, London, Engineering Geology Special Publication **, (on CD-ROM Paper 382).

LOOPE, D. B. MASON, J. A., \& DINGUS, L. 1999. Lethal sandslides from eolian dunes. The Journal of Geology, 107, 707-713.

MASLIN, M., OWEN, M., DAY, S. \& LONG, D. 2004. Linking continental-slope failures and climate change: testing the clathrate gun hypothesis. Geology, 32, 1, 53-56.

MAXIMOVICH, N. 2009. Use of alkaline waste products for acid mine water purification. In: Culshaw M. G., Reeves H. J., Jefferson I. \& Spink T. W. (eds). Engineering geology for tomorrow's cities. Geological Society, London, Engineering Geology Special Publication **, (on CD-ROM Paper 225).

MEEHL, G. A., ZWIERS, F., EVANS, J., KNUTSON, T., MEARNS, L. \& WHETTON, P. 2000. Trends in extreme weather and climate events: issues related to modelling extremes in projections of future climate change. Bulletin of the American Meteorological Society. 81, 3, 427 - 436.

NICHOLLS, R. J., HOOZEMANS, F. M. J. \& MARCHAND, M. 1999. Increasing flood risk and wetland losses due to global sea-level rise: regional and global analyses. Global Environmental Change, 9, S69-S87.

OFFICE OF THE DEPUTY PRIME MINISTER (ODPM). 2001. Planning Policy Guidance Note 25 Development and Flood Risk. The Stationery Office, London.

PHILLIPS, E. 2006. Micromorphology of a debris flow deposit: evidence of basal shearing, hydrofracturing, liquefaction and rotational deformation during emplacement. Quaternary Science Reviews, 25, 720-738.

PRUDHOMME, C., JAKOB, D. AND SVENSSON, C. 2003. Uncertainty and climate change impact on the flood regime of small UK catchments. Journal of Hydrology, 277, 1-23.

RACK, F., SKINNER, A. \& AMMAN, H. 2000. Coring and high pressure sampling. In: Robertson, K. G. \& Rietveld, M. J. (eds). Proceedings of INMARTECH 2000, Internatioanl Marine Technicians Workshop, Texel, The Netherlands. Royal Netherlands Institute for Sea Research (NIOZ), Texel, 113-119.

*REES, J. G., GIBSON, A. D., HARRISON, M., HUGHES, A. \& WALSBY, J. C. 2009. Regional modelling of geohazard change. In: Culshaw M. G., Reeves H. J., Jefferson I. \& Spink T. W. (eds) Engineering Geology for Tomorrow's Cities. Geological Society, London, Engineering Geology Special Publication **, xxx-xxx.

ROBERTS, J, PYMAR, C.F., WALLACE, J.S. AND PITMAN, R.M. 1980. Seasonal changes in leaf area, stomatal and canopy conductances and transpiration from baracken below a forest canopy. Journal of Applied Ecology, 17, 409 - 422.

SANNER, B., REUSS, M., MANDS, E. \& MULLER, J. 2000a. Thermal response test-experiences in Germany. Company Report, UBeG, Zum Boden 6, D-35580 Wetzlar. 6p.

SANNER, B., KARYTSAS, C, MENDRINOS, D. \& RYBACH, L. 2000b. Current status of ground source heat pumps and underground thermal energy storage in Europe. Company Report, UBeG, Zum Boden 6, D-35580 Wetzlar. 9p.

SAYRE, D. M. \& BULBULKAYA, A. 2009. Rocketts Landing, Richmond, Virginia, USA, brownfield redevelopment under voluntary remediation. In: Culshaw M. G., Reeves H. J., Jefferson I. \& Spink T. W. (eds). Engineering geology for tomorrow's cities. Geological Society, London, Engineering Geology Special Publication **, (on CD-ROM Paper 678).

SERRIDGE, C. J. 2009. Some applications of ground improvement techniques in the urban environment. In: Culshaw M. G., Reeves H. J., Jefferson I. \& Spink T. W. (eds). Engineering geology for tomorrow's cities. Geological Society, London, Engineering Geology Special Publication **, (on CD-ROM Paper 296). 
SHERMAN, G. \& PARTINGTON, B. 2009. Abandoned mine subsidence prediction using British National Coal Board methods, Denver, Colorado. In: Culshaw M. G., Reeves H. J., Jefferson I. \& Spink T. W. (eds). Engineering geology for tomorrow's cities. Geological Society, London, Engineering Geology Special Publication **, (on CD-ROM Paper 640).

STATHAM, I. 1977. Earth surface sediment transport. Contemporary problems in geography. Clarendon Press, Oxford. 184p.

STREIT, J. E. \& HILLIS, R. R. 2004. Estimating fault stability and sustainable fluid pressures for underground storage of $\mathrm{CO}_{2}$ in porous rock. Energy, 29, 1445-1456.

SZLAFSZTEIN, C. Urban regulations and climate change in low lying coastal cities, State of Pará, Brazil. In: Culshaw M. G., Reeves H. J., Jefferson I. \& Spink T. W. (eds). Engineering geology for tomorrow's cities. Geological Society, London, Engineering Geology Special Publication **, (on CD-ROM Paper 58).

THOMAS, B. I., BROCKLEBANK, H. T. \& POWER, C. Implications of urban development on escarpment instability. In: Culshaw M. G., Reeves H. J., Jefferson I. \& Spink T. W. (eds). Engineering geology for tomorrow's cities. Geological Society, London, Engineering Geology Special Publication **, (on CD-ROM Paper 533).

TOMLINSON, M. J. 1995. Foundation design and construction. $6^{\text {th }}$ Edition. Longman Scientific and Technical, Harlow, UK, 536p.

TUCKER, G. E. \& SLINGERLAND, R. 1997. Drainage basin responses to climate change. Water Resources Research, 33, 8, 2031-2047.

UNEP. 2007. The fourth Global environment outlook - environment for development (GEO-4) 2007, United Nations Environment Programme, Nairobi.

WADE, S., HOSSELL, J., HOUGH, M. \& FENN, C. (EDS). 1999. THE IMPACTS OF CLIMATE CHANGE IN THE SOUTH EAST IN THE $21^{\text {ST }}$ CENTURY. TECHNICAL REPORT. W. S. ATKINS, EPSOM, SURREY, UK. 94P.

WALTHAM, A. C. 2002. Foundations of Engineering Geology. $2^{\text {nd }}$ Edition. Spon Press, London. 92p.

WEST, T. R. \& CHO, K. 2009. Environmental and social issues associated with aggregate extraction: The Lafayette - West Lafayette, Indiana, and other examples, USA. In: Culshaw M. G., Reeves H. J., Jefferson I. \& Spink T. W. (eds). Engineering geology for tomorrow's cities. Geological Society, London, Engineering Geology Special Publication **, (on CD-ROM Paper 692).

WILSON, S., BRAY, R. \& COOPER, P. 2004. Sustainable drainage systems. Hydraulic, structural and water quality advice (C609). Construction Industry Research and Information Association, London, - 320 p.

WOODS BALLARD, B., KELLAGHER, R., MARTIN, P., JEFFRIES, C., BRAY, R. \& SHAFFER, P. 2007. The SUDS manual. Publication C697). Construction Industry Reasearch and Information Association, London. 600p.

YU, M-H., JEFFERSON, I. \& CULSHAW, M. G. 2009. Geohazards caused by rising groundwater in the Durham Coalfield, UK. In: Culshaw, M. G., Reeves, H. J., Jefferson, I. \& Spink, T. W. (eds). Engineering geology for tomorrow's cities. Geological Society, London, Engineering Geology Special Publication **, (on CD-ROM Paper 367).

ZHANG, K., DOUGLAS, B. C. \& LEATHERMAN, S. P. 2004. Global warming and coastal erosion. Climatic Change, 64, 1-2, 41-58.

ZOURMPAKIS, A., BOARDMAN, D.I., ROGERS, C.D.F., JEFFERSON, I., GUNN, D.A., JACKSON, P.D., NORTHMORE, K.J., ENTWISLE, D.C., NELDER, L.M. \& DIXON, N. 2006. Case study of a loess collapse field trial in Kent, SE England. Quarterly Journal of Engineering Geology and Hydrogeology, 39, 131-150. 